\title{
PROVISION OF CLIMATE SERVICES FOR AGRICULTURE Public and Private Pathways to Farm Decision-Making
}

\author{
Tonya Haigh, Vikram Koundinya, Chad Hart, Jenna Klink, Maria lemos, \\ Amber Saylor Mase, Linda Prokopy, Ajay Singh, Dennis Todey, and Melissa Widhalm
}

In a U.S. Corn Belt study, we found that agricultural advisors are engaged and critically important users of climate information, while gaps remain in providing salient climate information to farmers.

$\mathrm{T}$ he vagaries of weather and the shifts of climate patterns have significant implications for agricultural production. Farmers must make

\begin{abstract}
AfFILIATIONS: HAIGH-National Drought Mitigation Center, University of Nebraska-Lincoln, Lincoln, Nebraska; KoundINYADepartment of Human Ecology, University of California, Davis, and University of California Cooperative Extension, Davis, California; HART-Department of Economics, lowa State University, Ames, lowa; KLINK-Program Support Services, University of WisconsinExtension, Madison, Wisconsin; Lemos-School for Environment and Sustainability, University of Michigan, Ann Arbor, Michigan; MASE-Environmental Resources Center, University of WisconsinMadison, Madison, Wisconsin; PrOKOPY_Department of Forestry and Natural Resources, Purdue University, Lafayette, Indiana; SINGH-Department of Environmental Studies, California State University, Sacramento, Sacramento, California; TODEY-National Laboratory for Agriculture and the Environment, Agriculture Research Service, U.S. Department of Agriculture, Ames, lowa; WidHalm-Purdue Climate Change Research Center, Purdue University, Lafayette, Indiana CORRESPONDING AUTHOR: Tonya Haigh, thaigh2@unl.edu
\end{abstract}

The abstract for this article can be found in this issue, following the table of contents.

DOI:10.II75/BAMS-D-17-0253.I

In final form 2 March 2018

(C)2018 American Meteorological Society

For information regarding reuse of this content and general copyright

information, consult the AMS Copyright Policy. decisions on a variety of short- and long-term issues that affect their potential production, with almost all of these decisions influenced by weather and/or climate patterns (Stone and Meinke 2006; Hollinger 2009; Takle et al. 2014; Haigh et al. 2015b), making climate services critical to agriculture. Providers of climate services have the goal of creating usable information for decision-makers such as farmers through observational infrastructure and research and the development of decision-support products based on the interpretation of data and outlooks (National Research Council 2003; Miles et al. 2006; Brasseur and Gallardo 2016; Shafer et al. 2016).

While the need for these services appears to be high, the adoption of climate information by farmers is reportedly low (Ash et al. 2007; Crane et al. 2010; Marshall et al. 2011), and finding solutions for increasing adoption has been the goal of research and development in climate sciences. Much of this work builds upon an influential body of scholarship suggesting that three factors are critical in shaping the willingness of decision-makers to use scientific information: credibility, legitimacy, and salience (Cash et al. 2002; Kirchhoff et al. 2013). Conceptually, credibility may be thought of as the accuracy or plausibility of the information, legitimacy as whether the information and its sources are unbiased and fair, and salience as how relevant and timely the information 
is for addressing the problems important to the user. These factors identify important characteristics of the information itself and the information provider, but less so the effect of the process of developing or delivering the information.

A growing body of research has focused on the process of the coproduction of information to increase its usability, emphasizing iterations of communication between producers and users of knowledge to best meet users' needs (Lemos and Morehouse 2005; Dilling and Lemos 2011; Lemos et al. 2012; Prokopy et al. 2017). This approach is embraced by the National Oceanic and Atmospheric Administration's (NOAA) Regional Integrated Sciences and Assessments (RISA) programs and has also led to new products for agriculture, including the AgClimate tools developed for the southeastern United States and the suite of "Useful to Usable" tools developed for the U.S. Corn Belt (Fraisse et al. 2006; Kirchhoff et al. 2013; Prokopy et al. 2017).

The production of information is changing, as is the path (or paths) between information provider and end user, which may affect the perceived usability of the information. In the agricultural sector, state climatologists, regional climate centers, and extension educators historically have been the primary producers and deliverers of climate information at the state and local levels (Prokopy et al. 2015). Private sector advisors, including certified crop advisors and farm input sales providers, have had an expanding role as primary trusted providers of farm production advice, and as information intermediaries of related weather and climate information (Lemos et al. 2014; Haigh et al. 2015a; Prokopy et al. 2017). Despite the growing importance of their role, little is known about the perceptions and needs of the farm advisors who may be communicating climate information to their clients (Mase and Prokopy 2014).

In recent years, a growing number of private organizations, many as part of agricultural corporations (e.g., Climate Corporation), have begun to offer climate information directly to farmers. The agricultural input sector increasingly provides information both bundled with other services (such as agricultural advice and products) and as stand-alone products. Some agricultural corporations also provide proprietary weather and climate information exclusively to their employees, who may use it to inform the advice they provide to farmer clients. While little research has focused on this new format of climate information, there are reasons to predict that privately provided information might be received and used differently from publicly provided information. Empirical research finds that the relationship between producers and users of information, the format through which the information is provided, and the business model adopted by the provider are key variables in information adoption (Kirchhoff 2013; Brasseur and Gallardo 2016). Lemos et al. (2012) suggest that information is perceived as more usable through improved formatting, packaging, and visualization; wholesaling; retailing; and customization. Most private weather/ climate corporations rely on federally collected long-term datasets, models, and outlooks to produce their climate service products; however, because private companies and public entities have different resources, organizational goals, timelines, and strategies for marketing and tailoring information, it is likely that adoption of the resulting information products can also differ.

As the paths between climate information producers and agricultural decision-makers evolve and become more complex, it is not well understood how farmers' use of climate information is affected. In this study, we build on past research to depict pathways of public and private climate services provision for agriculture. We set out to improve our understanding of the various channels of information flow and the needs and preferences of information intermediaries and end users. Our research questions include the following:

1) What are the pathways of climate information provision to farmers as end users?

2) As information intermediaries, where are farm advisors looking for climate information?

3) Are farmers' and advisors' choices among climate service providers consistent with their perception of the salience, legitimacy, and credibility of those providers?

\section{RESEARCH QUESTIONS AND METHODS.}

We use survey data from over 5,500 respondents (farmers and advisors) in 12 Midwest and Great Plains states of the United States to investigate the research questions posed above. We conducted the survey in 2016, as part of the evaluation of a U.S. Department of Agriculture (USDA) project (Prokopy et al. 2017) called Useful to Usable. An interdisciplinary, multiuniversity team of researchers developed the survey, which included the subset of questions used in this analysis. This analysis considers the following topics of interest (the exact question wording can be found in the results tables; see Tables 1-3): 
TABLE I. Climate information use and extent of influence of the different climate information sources on advising and farming decisions of agricultural advisors and farmers.

\begin{tabular}{|c|c|c|c|c|c|c|}
\hline \multirow[b]{2}{*}{$\begin{array}{l}\text { Respondent } \\
\text { group }\end{array}$} & \multicolumn{2}{|c|}{ Use } & \multicolumn{4}{|c|}{ Extent of influence } \\
\hline & Yes & $\mathbf{n}$ & $\begin{array}{c}\text { Not } \\
\text { influential }\end{array}$ & $\begin{array}{l}\text { Somewhat } \\
\text { influential }\end{array}$ & $\begin{array}{c}\text { Very } \\
\text { influential }\end{array}$ & n \\
\hline \multicolumn{7}{|c|}{ Subscription or purchased weather/climate services (e.g., MyDTN, FieldView Plus or Pro) } \\
\hline All farmers & $17 \%$ & 1,462 & $15 \%$ & $62 \%$ & $23 \%$ & 281 \\
\hline All advisors & $20 \%$ & 2,200 & $34 \%$ & $51 \%$ & $15 \%$ & 752 \\
\hline \multicolumn{7}{|c|}{ Free and publicly available weather/climate information provided by a company (e.g., FieldView Prime, Pioneer360 tools) } \\
\hline All farmers & $31 \%$ & 1,456 & $15 \%$ & $70 \%$ & $15 \%$ & 451 \\
\hline All advisors & $49 \%$ & 2,197 & $15 \%$ & $67 \%$ & $18 \%$ & 1,178 \\
\hline \multicolumn{7}{|c|}{$\begin{array}{l}\text { Free weather/climate services provided by a university or government agency, including an extension program [e.g., lowa } \\
\text { State University (ISU) corn nitrogen rate calculator, University of Missouri Nitrogen Watch, University of Nebraska-Lincoln } \\
\text { (UNL) CornSoyWater] }\end{array}$} \\
\hline All farmers & $23 \%$ & $\mathrm{I}, 452$ & $11 \%$ & $75 \%$ & $14 \%$ & 360 \\
\hline All advisors & $67 \%$ & 2,186 & $12 \%$ & $66 \%$ & $22 \%$ & 1,505 \\
\hline \multicolumn{7}{|c|}{ Proprietary weather/climate information provided to employees of the company I work for } \\
\hline All advisors & $20 \%$ & 2,155 & $37 \%$ & $48 \%$ & $15 \%$ & 703 \\
\hline \multicolumn{7}{|c|}{ Weather/climate information provided personally by a farm advisor whom I pay } \\
\hline All farmers & $4 \%$ & 1,453 & $39 \%$ & $43 \%$ & $19 \%$ & 80 \\
\hline \multicolumn{7}{|c|}{ Weather/climate information provided personally by a farm advisor whom I do not pay } \\
\hline All farmers & $8 \%$ & 1,454 & $23 \%$ & $65 \%$ & $11 \%$ & 142 \\
\hline \multicolumn{7}{|c|}{ None of these sources are used } \\
\hline All farmers & $49 \%$ & $1,46 \mid$ & - & - & - & - \\
\hline All advisors & $17 \%$ & 2,213 & - & - & - & - \\
\hline
\end{tabular}

- respondents' use of various generalized types of weather/climate information, including subscription or purchased, free provided by a company, free provided by a university or government agency, proprietary (advisors only), and provided by an advisor (farmers only);

- if a particular type of information is used, how influential it is to respondents' advising or farming decisions, with options of "not influential," "somewhat influential," and "very influential";

- respondents' ascription of seven indicators of information salience, two indicators of credibility, and two indicators of legitimacy as being "more true for public providers," "more true for private providers," "equally true for both," or "not true for either," with the option to answer, "I don't know."

The survey was administered to farmers and advisors in Illinois, Indiana, Iowa, Kansas, Michigan, Minnesota, Missouri, Nebraska, North Dakota, Ohio, South Dakota, and Wisconsin, after pretesting with farmers and advisors who were not part of the survey sample. We administered the farmer version of the survey via mail (with the option to participate online) to a random sample $(n=6,849)$ of more than 350,000 individuals who received federal assistance for growing corn through the U.S. Department of Agriculture Farm Services Agency in 2013 and 2014. Of the 6,849 farmers we surveyed, 2,633 (39.1\%) responded. Because our sample frame included nonfarming landowners, we excluded respondents who indicated they are not actively engaged in agricultural production, reducing the number of responses to 1,536 .

We administered the advisor version of the survey online to the full population of advisors identified in each state. For this study, advisors are defined as those providing production and conservation advice to farmers in roles of certified crop advisors, technical service providers, or employees of university extension programs or conservation agencies $(n=10,760)$. All potential participants received 
TABLE 2. Agricultural advisors and farmers' views about the credibility and legitimacy of climate information provided by public and private providers. Boldface values in the chi-square column indicate $p<0.05$.

\begin{tabular}{|c|c|c|c|c|c|c|c|c|}
\hline & & $\begin{array}{c}\text { Not } \\
\text { true for } \\
\text { either }\end{array}$ & $\begin{array}{l}\text { More } \\
\text { true for } \\
\text { public }\end{array}$ & $\begin{array}{c}\text { Equally } \\
\text { true for } \\
\text { both }\end{array}$ & $\begin{array}{l}\text { More } \\
\text { true for } \\
\text { private }\end{array}$ & $\begin{array}{l}\text { I don't } \\
\text { know }\end{array}$ & n & $\begin{array}{l}\text { Chi } \\
\text { square }\end{array}$ \\
\hline \multicolumn{9}{|c|}{ The information is accurate } \\
\hline \multirow[t]{2}{*}{ Farmers } & No use & $12 \%$ & $5 \%$ & $30 \%$ & $4 \%$ & $49 \%$ & 630 & $87.02^{\mathrm{a}}$ \\
\hline & $\begin{array}{l}\text { Private only/ } \\
\text { Includes public }\end{array}$ & $7 \% / 8 \%$ & $3 \% / 8 \%$ & $48 \% / 48 \%$ & $11 \% / 10 \%$ & $31 \% / 26 \%$ & $288 / 390$ & 7.61 \\
\hline \multirow[t]{2}{*}{ Advisors } & No use & $3 \%$ & $5 \%$ & $32 \%$ & $1 \%$ & $58 \%$ & 323 & $111.23^{a}$ \\
\hline & $\begin{array}{l}\text { Private only/ } \\
\text { Includes public }\end{array}$ & $6 \% / 3 \%$ & $4 \% / 10 \%$ & $51 \% / 53 \%$ & $13 \% / 5 \%$ & $26 \% / 29 \%$ & $292 / 1,237$ & $35.82^{\mathrm{b}}$ \\
\hline \multicolumn{9}{|c|}{ The provider of the information is trustworthy } \\
\hline \multirow[t]{2}{*}{ Farmers } & No use & $6 \%$ & $7 \%$ & $34 \%$ & $3 \%$ & $51 \%$ & 633 & $95.93^{\mathrm{a}}$ \\
\hline & $\begin{array}{l}\text { Private only/ } \\
\text { Includes public }\end{array}$ & $3 \% / 4 \%$ & $6 \% / 11 \%$ & $50 \% / 49 \%$ & $10 \% / 10 \%$ & $31 \% / 26 \%$ & $288 / 393$ & 6.17 \\
\hline \multirow[t]{2}{*}{ Advisors } & No use & $3 \%$ & $9 \%$ & $30 \%$ & $1 \%$ & $57 \%$ & 327 & $126.10^{\mathrm{a}}$ \\
\hline & $\begin{array}{l}\text { Private only/ } \\
\text { Includes public }\end{array}$ & $2 \% / 2 \%$ & $7 \% / 18 \%$ & $55 \% / 50 \%$ & $8 \% / 4 \%$ & $27 \% / 26 \%$ & $301 / 1,254$ & $31.45^{b}$ \\
\hline \multicolumn{9}{|c|}{ The information is used as a way to sell farmers something } \\
\hline \multirow[t]{2}{*}{ Farmers } & No use & $9 \%$ & $4 \%$ & $21 \%$ & $18 \%$ & $48 \%$ & 631 & $98.28^{a}$ \\
\hline & $\begin{array}{l}\text { Private only/ } \\
\text { Includes public }\end{array}$ & $13 \% / 10 \%$ & $3 \% / 5 \%$ & $22 \% / 19 \%$ & $36 \% / 42 \%$ & $26 \% / 24 \%$ & $287 / 393$ & 4.50 \\
\hline \multirow[t]{2}{*}{ Advisors } & No use & $8 \%$ & $2 \%$ & $17 \%$ & $17 \%$ & $52 \%$ & 326 & $1 / 8.37^{a}$ \\
\hline & $\begin{array}{l}\text { Private only/ } \\
\text { Includes public }\end{array}$ & $17 \% / 13 \%$ & $2 \% / 2 \%$ & $20 \% / 21 \%$ & $35 \% / 38 \%$ & $26 \% / 26 \%$ & $298 / 1,240$ & 5.16 \\
\hline \multicolumn{9}{|c|}{$\begin{array}{l}\text { The way the information is distributed to farmers is fair } \\
\text { The way the information is distributed to farmers and advisors is fair }\end{array}$} \\
\hline \multirow[t]{2}{*}{ Farmers } & No use & $5 \%$ & $7 \%$ & $28 \%$ & $4 \%$ & $55 \%$ & 631 & $76.23^{a}$ \\
\hline & $\begin{array}{l}\text { Private only/ } \\
\text { Includes public }\end{array}$ & $4 \% / 4 \%$ & $7 \% / 15 \%$ & $48 \% / 44 \%$ & $7 \% / 6 \%$ & $35 \% / 32 \%$ & $286 / 393$ & $10.37^{b}$ \\
\hline \multirow[t]{2}{*}{ Advisors } & No use & $3 \%$ & $5 \%$ & $27 \%$ & $1 \%$ & $64 \%$ & 326 & $134.80^{a}$ \\
\hline & $\begin{array}{l}\text { Private only/ } \\
\text { Includes public }\end{array}$ & $2 \% / 1 \%$ & $14 \% / 18 \%$ & $50 \% / 46 \%$ & $5 \% / 3 \%$ & $30 \% / 32 \%$ & $300 / 1,254$ & 6.93 \\
\hline
\end{tabular}

a The chi-square statistic indicates results of tests of independence of the No use group compared to the combined Private only/lncludes public group.

b The chi-square statistic indicates results of tests of independence of the Private only group compared to the Includes public group.

presurvey notifications and/or multiple reminders to take the survey (Dillman et al. 2014). We received responses from 3,098 (28.7\%) of the 10,760 advisors. Of those responding, 2,719 confirmed that they advised farmers and/or other advisors and were included in our analysis.

We use the proportion of farmers and advisors employing each type of information, and the level of influence they ascribe to the information, to address research questions 1 and 2 . To address research question 3, whether the use of information aligns with perceptions of salience, credibility, and legitimacy, we compare three subgroups of the advisors and farmers:

1) individuals who reported that they did not use any of the sources of weather/climate information included in the survey (subscription, free provided by private company, free provided by public university or agency, proprietary, or any advisor);

2) individuals who reported using only privately provided weather/climate information, defined 
as subscription, free provided by company, proprietary, or paid advisor (but not free provided by public sources or free advisor);

3) individuals who reported using free, publicly provided weather/climate information, either exclusively or in combination with one of the private sources of information.

In all cases we use the chi-square statistic to test the independence of the groups $(\alpha=0.05)$.

RESULTS. Research question I: What are the pathways of climate information provision to farmers as end users? About half of all farmers said they did not use any of the types of weather/climate information included in the survey. Approximately one-third of farmers said they used free weather/climate information provided by a company, and slightly fewer $(23 \%)$ said they used free weather/climate services provided by a university or government agency, including extension programs. Approximately $17 \%$ said they were directly paying for weather/climate information through a subscription or purchased service, while $4 \%-8 \%$ said they received information personally from a paid or unpaid advisor. Of those who use each type of information, there were no statistically significant differences in the level of influence ascribed to any type, with most farmers rating all sources as "somewhat influential" (Table 1).

Research question 2: As information intermediaries, where are farm advisors looking for climate information? Advisors' use of weather/climate information differed from that of farmers. Advisors were approximately 3 times more likely than farmers were to use weather and climate services provided for free by either a for-profit company or a university or government agency. Moreover, advisors were much less likely than farmers to say they did not use any of the sources (17\% compared to $49 \%$ ). Like farmers, approximately $20 \%$ of advisors are currently paying for some type of subscription related to climate information. About the same proportion said they access proprietary weather/climate information through their employer. Advisors ascribed higher levels of influence to weather/climate information provided free by public or private entities than they did to information they purchased or accessed through their company of employment (Table 1).

Research question 3: Are farmers' and advisors' choices among climate service providers consistent with their perception of the salience, legitimacy, and credibility of those providers? In general, a large number of farmers and advisors said that publicly and privately provided weather/climate information is equally salient, credible, and legitimate. Two overall differences stand out: about $25 \%$ of all respondents said privately provided weather/climate information is more specific to farmers' fields, and about $30 \%$ said privately provided weather/climate information is more likely to be used as a way to sell something.

We found that advisors and farmers appear to weigh salience, credibility, and legitimacy differently when choosing sources of information. Advisors who reported using only private sources of weather/ climate information were more likely to favor private information in their perceptions of the timeliness, importance, specificity, relevance, competitive advantage, and effect of financial risk and yield compared to those who also used publicly provided information. They also differed in how they viewed the accuracy and trustworthiness of the information, but not the fairness of the information or its use to sell farmers something.

In contrast, farmers who used only privately produced weather/climate information did not differ from those who also used public information in their perceptions of the accuracy, trustworthiness, timeliness, importance, specificity, yield, or advantage of either provider. Using private information seemed to increase equivalence about the relevance, fairness, and ability of information to reduce financial risk, with increased percentages of respondents saying neither group was relevant or reduced risk or that they did not know. Farmers who used none of the sources of information were also more likely than others to say that neither public nor private information was salient, legitimate, or credible. Survey responses are summarized in Tables 2 and 3.

The percentage of respondents who selected the "I don't know" option was high across all questions, a somewhat unexpected result. Farmers and advisors who reported using none of the weather/climate information types listed were most likely to answer I don't know on all questions. The statement that drew the highest percentage of I don't know answers from both farmers and advisors was "the information provides a competitive edge over other farmers."

DISCUSSION. The rapid proliferation of different types of information, and the growing focus on climate adaptation in general, calls attention to the future of climate services provision (Brasseur and Gallardo 2016; Miles et al. 2006; Vaughan and Dessai 2014). Our findings confirm that much weather and climate information is not reaching farmers and draw 
TABLE 3. Agricultural advisors and farmers' views about the salience of climate information provided by public and private providers. Boldface values in the chi-square column indicate $p<0.05$.

$\begin{array}{ccccccc}\begin{array}{c}\text { Not } \\ \text { true for } \\ \text { either }\end{array} & \begin{array}{c}\text { More } \\ \text { true for } \\ \text { public }\end{array} & \begin{array}{c}\text { Equally } \\ \text { true for } \\ \text { both }\end{array} & \begin{array}{c}\text { More } \\ \text { true for } \\ \text { private }\end{array} & \begin{array}{c}\text { I don't } \\ \text { know }\end{array} & n & \begin{array}{c}\text { Chi } \\ \text { square }\end{array}\end{array}$

The information is provided in time for me to make a decision

$\begin{array}{ccccccccc}\text { Farmers } & \text { No use } & 8 \% & 9 \% & 34 \% & 6 \% & 43 \% & 638 & 92.59^{a} \\ & \begin{array}{c}\text { Private only/ } \\ \text { Includes public }\end{array} & 6 \% / 6 \% & 8 \% / 8 \% & 49 \% / 53 \% & 13 \% / 14 \% & 24 \% / 19 \% & 291 / 391 & 3.19\end{array}$

The information is provided in time for me to provide advice on a decision

$\begin{array}{cccccccrr}\text { Advisors } & \text { No use } & 4 \% & 5 \% & 29 \% & 4 \% & 57 \% & 334 & 146.26^{\mathrm{a}} \\ & \begin{aligned} \text { Private only/ } \\ \text { Includes public }\end{aligned} & 4 \% / 2 \% & 6 \% / 8 \% & 47 \% / 53 \% & 21 \% / 11 \% & 21 \% / 26 \% & 303 / 1,270 & \mathbf{2 8 . 8 6} \mathbf{b}^{\mathrm{b}} \\ & & & & & & & \end{array}$

The information addresses the most important decisions or problems in corn production

\begin{tabular}{|ccccccccc} 
Farmers & No use & $12 \%$ & $4 \%$ & $25 \%$ & $9 \%$ & $50 \%$ & $\begin{array}{c}631 \\
66.57^{\mathrm{a}}\end{array}$ \\
& $\begin{array}{l}\text { Private only/ } \\
\text { Includes public }\end{array}$ & $15 \% / 14 \%$ & $3 \% / 6 \%$ & $34 \% / 35 \%$ & $17 \% / 18 \%$ & $31 \% / 27 \%$ & $290 / 389$ & 4.71 \\
\hline Advisors & No use & $6 \%$ & $2 \%$ & $24 \%$ & $8 \%$ & $60 \%$ & 328 & 101.02 \\
& $\begin{array}{l}\text { Private only/ } \\
\text { Includes public }\end{array}$ & $10 \% / 7 \%$ & $3 \% / 5 \%$ & $38 \% / 42 \%$ & $20 \% / 14 \%$ & $28 \% / 32 \%$ & $301 / 1,253$ & $13.677^{\mathrm{b}}$ \\
& & & & & & & \\
\hline
\end{tabular}

The information is specific to my farm needs

$\begin{array}{ccccccccc}\text { Farmers } & \text { No use } & 18 \% & 5 \% & 19 \% & 13 \% & 45 \% & 634 & 128.23{ }^{a} \\ & \begin{array}{l}\text { Private only/ } \\ \text { Includes public }\end{array} & 15 \% / 16 \% & 4 \% / 5 \% & 22 \% / 22 \% & 38 \% / 35 \% & 21 \% / 21 \% & 288 / 392 & 0.71\end{array}$

The information is specific to the fields of farmers I advise

$\begin{array}{ccccccccc}\text { Advisors } & \text { No use } & 9 \% & 4 \% & 22 \% & 9 \% & 56 \% & 329 & 121.30^{\mathrm{a}} \\ & \begin{array}{c}\text { Private only/ } \\ \text { Includes public }\end{array} & 11 \% / 9 \% & 3 \% / 5 \% & 23 \% / 30 \% & 38 \% / 28 \% & 24 \% / 28 \% & 299 / 1,260 & 16.0 I^{\mathrm{b}}\end{array}$

The information is relevant to the decisions I make

\begin{tabular}{|c|c|c|c|c|c|c|c|c|}
\hline \multirow[t]{2}{*}{ Farmers } & No use & $10 \%$ & $8 \%$ & $37 \%$ & $7 \%$ & $38 \%$ & 633 & $115.12^{a}$ \\
\hline & $\begin{array}{l}\text { Private only/ } \\
\text { Includes public }\end{array}$ & $10 \% / 4 \%$ & $4 \% / 8 \%$ & $49 \% / 60 \%$ & $19 \% / \mid 4 \%$ & $18 \% / 15 \%$ & $288 / 392$ & $22.73^{b}$ \\
\hline \multirow[t]{2}{*}{ Advisors } & No use & $8 \%$ & $6 \%$ & $30 \%$ & $4 \%$ & $52 \%$ & 328 & $|59.5|^{a}$ \\
\hline & $\begin{array}{l}\text { Private only/ } \\
\text { Includes public }\end{array}$ & $3 \% / 3 \%$ & $5 \% / 10 \%$ & $53 \% / 56 \%$ & $19 \% / 9 \%$ & $20 \% / 23 \%$ & $300 / 1,263$ & $28.70^{b}$ \\
\hline
\end{tabular}

a picture of the current pathways of information that are reaching agricultural users. For farmers, private services such as subscription and free tools and applications (apps) appear to be as important as publicly provided services through universities, extension programs, and government agencies. Because this study focused on information services and tools that link to agricultural decisions, not general weather forecasts, mediums such as television, radio, newspapers, and weather websites and apps of all types are not included in the analysis (though they are clearly important).
The relatively low proportion of farmers indicating they receive weather/climate information personally from an advisor suggests that farmers may not be aware of the extent to which the information is packaged with seed, input, or management recommendations. Prior research indicates that many U.S. Corn Belt farmers get farm production advice through private and public sector advisors (Arbuckle and Ferrell 2012; Prokopy et al. 2017) and that farm advisors say they incorporate weather/climate information in the advice they provide (Haigh et al. 2015a). Yet many 
TABle 3. Continued.

$\begin{array}{ccccccc}\begin{array}{c}\text { Not } \\ \text { true for } \\ \text { either }\end{array} & \begin{array}{c}\text { More } \\ \text { true for } \\ \text { public }\end{array} & \begin{array}{c}\text { Equally } \\ \text { true for } \\ \text { both }\end{array} & \begin{array}{c}\text { More } \\ \text { true for } \\ \text { private }\end{array} & \begin{array}{c}\text { I don't } \\ \text { know }\end{array} & n & \begin{array}{c}\text { Chi } \\ \text { square }\end{array}\end{array}$

The information helps me reduce financial risks

$\begin{array}{ccccccccc}\text { Farmers } & \text { No use } & 16 \% & 3 \% & 24 \% & 5 \% & 52 \% & 632 & \mathbf{9 4 . 0 1}^{\mathrm{a}} \\ & \begin{array}{c}\text { Private only/ } \\ \text { Includes public }\end{array} & 18 \% / 12 \% & 3 \% / 6 \% & 36 \% / 50 \% & 9 \% / 9 \% & 34 \% / 23 \% & 288 / 393 & \mathbf{2 2 . 9 0 ^ { b }}\end{array}$

The information helps farmers that I advise reduce financial risks

$\begin{array}{ccccccccc}\text { Advisors } & \text { No use } & 7 \% & 3 \% & 27 \% & 2 \% & 62 \% & 329 & 118.83 \\ & \text { Private only/ } & 7 \% / 6 \% & 2 \% / 7 \% & 50 \% / 50 \% & 12 \% / 5 \% & 28 \% / 32 \% & 300 / 1,255 & 30.98^{\mathrm{b}} \\ & \text { Includes public } & & & & & & \end{array}$

The information leads to better crop yields

\begin{tabular}{|c|c|c|c|c|c|c|c|c|}
\hline \multirow[t]{2}{*}{ Farmers } & No use & $13 \%$ & $3 \%$ & $25 \%$ & $5 \%$ & $54 \%$ & 634 & $66.8 \mathrm{I}^{\mathrm{a}}$ \\
\hline & $\begin{array}{l}\text { Private only/ } \\
\text { Includes public }\end{array}$ & $13 \% / 12 \%$ & $3 \% / 2 \%$ & $36 \% / 45 \%$ & $9 \% / 9 \%$ & $39 \% / 29 \%$ & $288 / 393$ & 8.98 \\
\hline \multirow[t]{2}{*}{ Advisors } & No use & $5 \%$ & $2 \%$ & $27 \%$ & $4 \%$ & $61 \%$ & 328 & $73.97^{\mathrm{a}}$ \\
\hline & $\begin{array}{l}\text { Private only/ } \\
\text { Includes public }\end{array}$ & $7 \% / 7 \%$ & $2 \% / 2 \%$ & $44 \% / 46 \%$ & $13 \% / 7 \%$ & $34 \% / 37 \%$ & $297 / 1,245$ & $14.42^{b}$ \\
\hline
\end{tabular}

The information gives me a competitive advantage over other farmers

$\begin{array}{ccccccccc}\text { Farmers } & \text { No use } & 21 \% & 1 \% & 15 \% & 5 \% & 59 \% & 637 & 49.45^{\text {a }} \\ & \begin{array}{rlcl}\text { Private only/ } \\ \text { Includes public }\end{array} & 20 \% / 21 \% & 2 \% / 2 \% & 22 \% / 24 \% & 10 \% / 12 \% & 46 \% / 41 \% & 287 / 392 & 1.92^{\mathrm{b}} \\ & & & & & & & \end{array}$

The information gives me a competitive advantage over other farm advisors

$\begin{array}{ccccccccc}\text { Advisors } & \text { No use } & 16 \% & 2 \% & 17 \% & 2 \% & 64 \% & 329 & \mathbf{8 2 . 7 8}^{\text {a }} \\ & \begin{array}{l}\text { Private only/ } \\ \text { Includes public }\end{array} & 18 \% / 16 \% & 1 \% / 3 \% & 32 \% / 30 \% & 16 \% / 11 \% & 33 \% / 41 \% & 299 / 1,256 & 12.966^{\text {b }} \\ & & & & & & & \end{array}$

a The chi-square statistic indicates results of tests of independence of the no use group compared to the combined Private only/lncludes public group.

$\mathrm{b}$ The chi-square statistic indicates results of tests of independence of the Private only group compared to the Includes public group.

farmers do not believe they are receiving weather/ climate information from their advisors. We do not believe that the current findings contradict earlier findings; rather, it is likely that as climate information becomes more integrated into advisors' agricultural production or marketing recommendations, it may not be clear to farmers that they are benefiting from climate services.

Farmers' choices of private and public information are not highly related to their perceptions of legitimacy, credibility, or salience. Indeed, farmers appear to be skeptical of the salience of any weather/ climate information source, regardless of their information preferences. They are particularly doubtful that the information is specific, reduces financial risks, achieves better crop yields, addresses important decisions, and provides a competitive advantage over other farmers, even if they pay for it. Instead, their choices may be influenced by packaging and retailing strategies of agricultural companies, or in fact they may be receiving information involuntarily as part of a marketing package. We did not explicitly ask farmers about packaging and retailing, leaving this question to future studies.

Reinforcing the findings of Prokopy et al. (2013), Lemos et al. (2014), and Haigh et al. (2015a), we found that agricultural advisors are engaged users of weather/climate services. Given their willingness to have a role in translating weather/climate information into agricultural decision-making, understanding their needs and preferences will benefit the development of weather/climate services for this industry as a whole. Overall, response patterns suggest that advisors' information use is related to their perceptions of its credibility and salience. Contrary to expectations, though, perceived legitimacy was less useful in explaining advisors' use of private and public information. Advisors (and farmers) tend to believe 
that both publicly and privately provided information is fair and that the private sector is trying to make money from their products, despite their information preferences. Presently, the cost or pricing of climate information services may not pose an obstacle to individuals who want to use it. However, private organizations may choose to be responsive only to certain groups, while public agencies are expected to respond to all (Smith and Ingram 1993), and future changes in the industry could affect access and equity in ways not now a concern for users.

With regard to the I don't know answers, one explanation may be that farmers have not thought about this issue specifically or do not care one way or the other. The correlation between answering I don't know and not using any of the information supports this proposition. Further, had we asked about specific climate products, the respondents might have answered other than I don't know. However, it may also be that interaction and marketing strategies make farmers' and advisors' perceptions of salience, credibility, and legitimacy irrelevant, leading to the high number of I don't know answers in the survey. Additional qualitative analyses are needed to understand these responses, and more research is needed to address causal relationships.

CONCLUSIONS. Like other industries, agriculture has its own needs for decision-making using climate information, including tactical decisions throughout a growing season and longer-term decisions about soil management, marketing, and agricultural infrastructure. Better-coordinated climate services are needed to meet those needs, engaging advisors and farmers as key stakeholders, and strategically employing delivery pathways through the private and the public sector. A number of climate service functions may be developed de facto through the private provision of climate information to farmers in the United States (Haigh et al. 2015a; Lemos et al. 2014), but they do not necessarily replace more traditional providers, such as state climate offices and extension programs, in providing trusted information to advisors and farmers (Prokopy et al. 2015). In general, we find that strategies that employ differentiated types and delivery systems of information may best serve a diversity of users and enhance agricultural productivity and sustainability.

ACKNOWLEDGMENTS. This research is part of "Useful to Usable (U2U): Transforming Climate Variability and Change Information for Cereal Crop Producers" and is supported by Agriculture and Food Research Initiative
Competitive Grant 2011-68002-30220 from the USDA National Institute of Food and Agriculture (project website: www.AgClimate4U.org).

\section{REFERENCES}

Arbuckle, J., and J. Ferrell, 2012: Iowa farm and rural life poll: 2012 summary report. Iowa State University Extension and Outreach, $12 \mathrm{pp}$., https://store.extension .iastate.edu/Product/Iowa-Farm-and-Rural-Life -Poll-2012-Summary-Report.

Ash, A. P., B. McIntosh, P. Cullen, P. Carberry, and M. S. Smith, 2007: Constraints and opportunities in applying seasonal climate forecasts in agriculture. Crop Pasture Sci., 58, 952-965, https://doi .org/10.1071/AR06188.

Brasseur, G. P., and L. Gallardo, 2016: Climate services: Lessons learned and future prospects. Earth's Future, 4, 79-89, https://doi.org/10.1002/2015EF000338.

Cash, D., W. Clark, F. Alcock, N. Eckley, and J. Jäger, 2002: Salience, credibility, legitimacy and boundaries: Linking research, assessment and decision making. KSG Faculty Research Working Paper Series RWP02-046, 25 pp., https://dx.doi.org/10.2139 /ssrn.372280.

Crane, M., C. Roncoli, J. Paz, N. Breuer, K. Broad, K. T. Ingram, and G. Hoogenboom, 2010: Forecast skill and farmers' skills: Seasonal climate forecasts and agricultural risk management in the southeastern United States. Wea. Climate Soc., 2, 44-59, https:// doi.org/10.1175/2009WCAS1006.1.

Dilling, L., and M. C. Lemos, 2011: Creating usable science: Opportunities and constraints for climate knowledge use and their implications for science policy. Global Environ. Change, 21, 680-689, https:// doi.org/10.1016/j.gloenvcha.2010.11.006.

Dillman, D. A., J. D. Smyth, and L. M. Christian, 2014: Internet, Phone, Mail, and Mixed-Mode Surveys: The Tailored Design Method. John Wiley and Sons, 528 pp. Fraisse, C. W., and Coauthors, 2006: AgClimate: A climate forecast information system for agricultural risk management in the southeastern USA. Comput. Electron. Agric., 53, 13-27, https://doi.org/10.1016/j .compag.2006.03.002.

Haigh, T., L. W. Morton, M. C. Lemos, C. Knutson, L. S. Prokopy, Y. J. Lo, and J. Angel, 2015a: Agricultural advisors as climate information intermediaries: Exploring differences in capacity to communicate climate. Wea. Climate Soc., 7, 83-93, https://doi .org/10.1175/WCAS-D-14-00015.1.

—, E. Takle, J. Andresen, M. Widhalm, J. S. Carlton, and J. Angel, 2015b: Mapping the decision points and climate information use of agricultural producers 
across the U.S. Corn Belt. Climate Risk Manage., 7, 20-30, https://doi.org/10.1016/j.crm.2015.01.004.

Hollinger, S. E., 2009: Meteorological forecasting for agricultural production. Systems Analysis and Modeling in Food and Agriculture, K. C. Ting, D. H. Fleisher, and L. F. Rodriguez, Eds., Food and Agricultural Sciences, Engineering and Technology Resources Series, Encyclopedia of Life Support Systems Publishers, 397-409.

Kirchhoff, C. J., 2013: Understanding and enhancing climate information use in water management. Climatic Change, 119, 495-509, https://doi.org/10.1007 /s10584-013-0703-x.

—, M. C. Lemos, and S. Dessai, 2013: Actionable knowledge for environmental decision making: Broadening the usability of climate science. Annu. Rev. Environ. Resour., 38, 393-414, https://doi .org/10.1146/annurev-environ-022112-112828.

Lemos, M. C., and B. J. Morehouse, 2005: The co-production of science and policy in integrated climate assessments. Global Environ. Change, 15, 57-68, https://doi.org/10.1016/j.gloenvcha.2004.09.004.

—, C. J. Kirchhoff, and V. Ramprasad, 2012: Narrowing the climate information usability gap. Nat. Climate Change, 2, 789-794, https://doi.org/10.1038 /nclimate1614.

— , Y. J. Lo, C. J. Kirchhoff, and T. Haigh, 2014: Crop advisors as climate information brokers: Building the capacity of US farmers to adapt to climate change. Climate Risk Manage., 4-5, 32-42, https:// doi.org/10.1016/j.crm.2014.08.001.

Marshall, N. A., I. J. Gordon, and J. Ash, 2011: The reluctance of resource-users to adopt seasonal climate forecasts to enhance resilience to climate variability on the rangelands. Climatic Change, 107, 511-529, https://doi.org/10.1007/s10584-010-9962-y.

Mase, A. S., and L. S. Prokopy, 2014: Unrealized potential: A review of perceptions and use of weather and climate information in agricultural decision making. Wea. Climate Soc., 6, 47-61, https://doi.org/10.1175 /WCAS-D-12-00062.1.
Miles, E. L., A. K. Snover, L. C. Whitely Binder, E. S. Sarachik, P. W. Mote, and N. Mantua, 2006: An approach to designing a national climate service. Proc. Natl. Acad. Sci. USA, 103, 19616-19623, https:// doi.org/10.1073/pnas.0609090103.

National Research Council, 2003: Fair Weather: Effective Partnerships in Weather and Climate Services. National Academies Press, 238 pp.

Prokopy, L. S., and Coauthors, 2013: Agricultural advisors: A receptive audience for weather and climate information? Wea. Climate Soc., 5, 162-167, https:// doi.org/10.1175/WCAS-D-12-00036.1.

—, J. G. Arbuckle, A. P. Barnes, V. R. Haden, A. Hogan, M. T. Niles, and J. Tyndall, 2015: Farmers and climate change: A cross-national comparison of beliefs and risk perceptions in high-income countries. Environ. Manage., 56, 492-504, https://doi .org/10.1007/s00267-015-0504-2.

—, J. S. Carlton, T. Haigh, M. C. Lemos, A. S. Mase, and M. Widhalm, 2017: Useful to usable: Developing usable climate science for agriculture. Climate Risk Manage., 15, 1-7, https://doi.org/10.1016/j .crm.2016.10.004.

Shafer, M., D. Brown, and C. McNutt, 2016: Managing the 2011 drought: A climate services partnership. Climate in Context: Science and Society Partnering for Adaptation, A. S. Parris et al., Eds., John Wiley and Sons, 191-212, https:/doi.org/10.1002/9781118474785.ch9.

Smith, S. R., and H. Ingram, 1993: Public Policy for Democracy. Brookings Institution Press, 274 pp.

Stone, R. C., and H. Meinke, 2006: Weather, climate, and farmers: An overview. Meteor. Appl., 13, 7-20, https://doi.org/10.1017/S1350482706002519.

Takle, E. S., and Coauthors, 2014: Climate forecasts for corn producer decision making. Earth Interact., 18, https://doi.org/10.1175/2013EI000541.1.

Vaughan, C., and S. Dessai, 2014: Climate services for society: Origins, institutional arrangements, and design elements for an evaluation framework. Wiley Interdiscip. Rev.: Climate Change, 5, 587-603, https:// doi.org/10.1002/wcc. 290. 


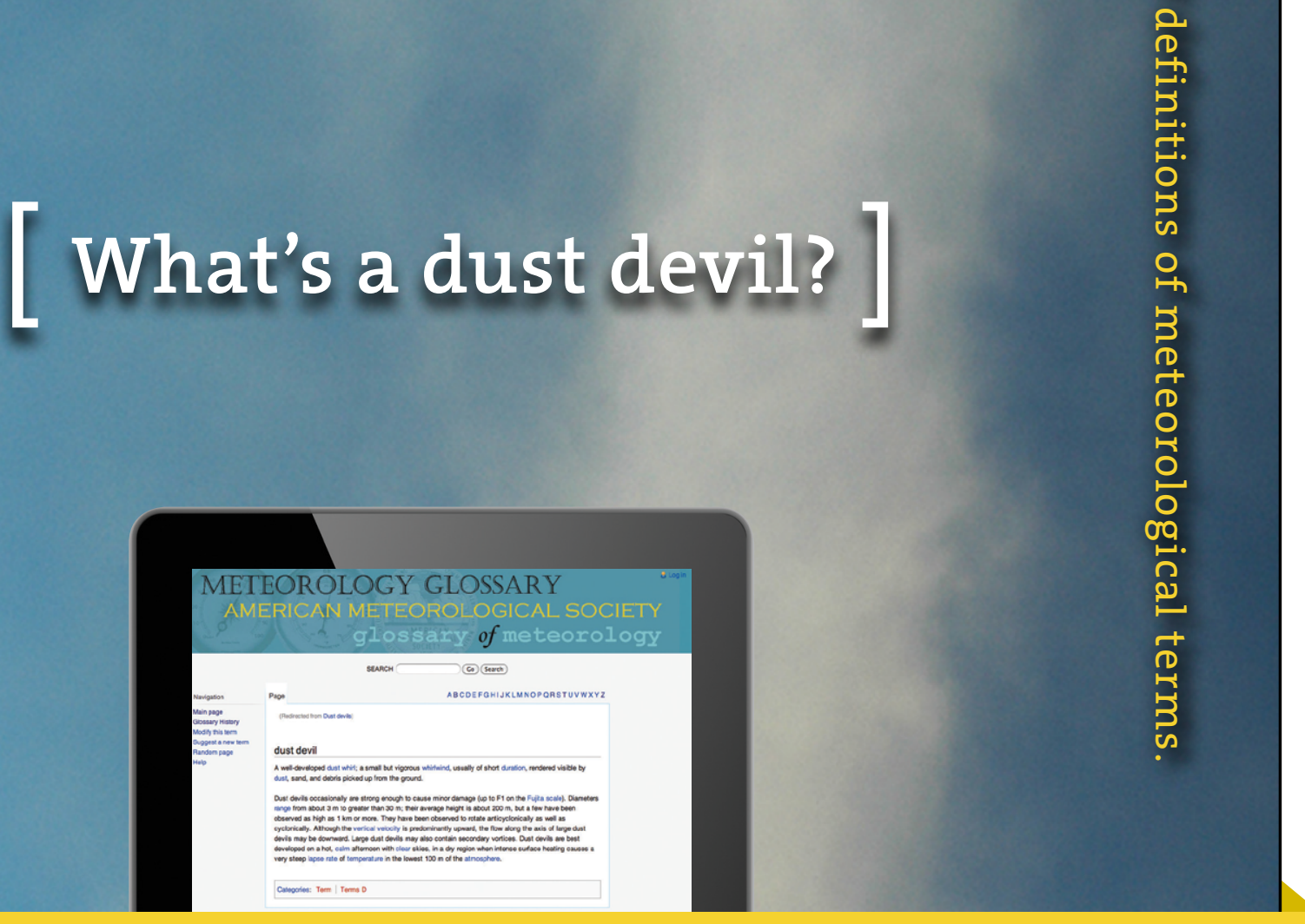

\section{THE AMERICAN METEOROLOGICAL SOCIETY \\ Online Glossary of Meteorology}

With over 12,000 meteorological terms, you'll be able to look up definitions online any time, any place, anywhere. http://glossary.ametsoc.org/wiki 